\title{
PENERAPAN MODEL PEMBELAJARAN JIGSAW UNTUK MENINGKATKAN PRESTASI BELAJAR SISWA PADA MATERI SEGI EMPAT
}

\author{
Niswatul Hamidah ${ }^{1}$, Sri Hariyani ${ }^{2}$, Rahaju ${ }^{3}$ \\ 1,2,3 Pendidikan Matematika, Universitas Kanjuruhan Malang, Indonesia \\ ${ }^{1}$ niswatul_hamidah28@yahoo.com \\ 2 srihariyani@unikama.ac.id \\ 3 ayurakoep@unikama.ac.id
}

\begin{abstract}
Abstrak: Prestasi belajar matematika siswa masih rendah, salah satu penyebab menurunnya prestasi belajar siswa yaitu metode konvensional yang kontinu sehingga siswa merasa bosan dan cenderung pasif dalam pembelajaran. Untuk mengatasi hal tersebut, guru menggunakan metode dan model pembelajaran yang bervariatif selama mengajar. Dalam penelitian ini, guru menggunakan model pembelajaran jigsaw. Adapun jenis penelitian yang digunakan adalah penelitian tindakan kelas (PTK). Subjek penelitian ini adalah siswa kelas VIIB SMP PGRI 4 Tirtoyudo sebanyak 24 anak, terdiri atas 12 siswa laki-laki dan 12 siswa perempuan. Prosedur pengumpulan data meliputi observasi, tes dan dokumentasi. Pembelajaran model jigsaw dapat meningkatkan prestasi belajar meliputi: (1) Guru membagi siswa menjadi beberapa kelompok; (2) Guru meminta anggota kelompok yang mempelajari materi yang sama berkumpul membentuk kelompok ahli; (3) Guru meminta kelompok ahli untuk mendiskusikan materi bagiannya; (4) Guru meminta siswa kembali ke kelompok asal dan menjelaskan materi yang dipelajari di kelompok ahli kepada rekan kelompoknya; dan (5) Guru menunjuk salah satu kelompok untuk mempresentasikan hasil diskusi kelompoknya di depan kelas. Hasil analisis tes siklus 1 menunjukkan bahwa siswa yang tuntas belajar sebanyak 19 siswa dari 24 siswa, sehingga persentase siswa yang tuntas belajar sebesar $79,10 \%$ dan prosentase siswa yang tidak tuntas belajar sebesar $20,90 \%$ dengan nilai rata-rata kelas 73,5.Hasil tes analisis siklus 2 menunjukkan bahwa siswa yang tuntas belajar sebanyak 22 siswa dari 24 siswa, sehingga persentase siswa yang tuntas belajar sebesar $91,67 \%$ dan persentase siswa yang tidak tuntas belajar sebesar 8,33\% dengan nilai rata-rata kelas 80,2.
\end{abstract}

Kata kunci: Jigsaw; Segiempat; Prestasi Belajar.

\begin{abstract}
Students'mathematics learning achievement is still low, one of the causes of decreasing student learning achievement is the continuous conventional method so that students feel bored and tend to be passive in learning. To overcome it, the teacher uses varied learning methods and models of teaching. In this study, the teacher used a jigsaw learning model. The type of research used is classroom action research (CAR). The subjects of this study were 24 students in a class, consisting of 12 male students and 12 female students. The procedure for collecting data includes observation, tests and documentation. The results of the study in cycle 1 were: (1) students were noisy at the time of group division; (2) there are students who dominate work activities in groups; (3) researchers can not allocate time; (4) some students who are not presentations pay less attention to the presenter and talk to their friends; and (5) some students lack confidence when taking the test. The results of test analysis at cycle 1 showed that students who finished learning were 19 students, so the percentage of students who completed learning was $79.10 \%$ and the percentage of students who did not complete the study was $20.90 \%$ and class average value was 73.5 . The results of analysis test at the cycle 2 showed that students who completed the study were 22 students, so the percentage of students who finished learning was $91.67 \%$ and the percentage of students who did not complete the study was $8.33 \%$ and class average value was 80.2 .
\end{abstract}

Keywords: Jigsaw; Quadrilateral; Learning Achieveme. 


\section{Pendahuluan}

Berdasarkan hasil wawancara dengan guru matematika kelas VII B diperoleh informasi bahwa: (1) siswa kurang antusias dalam pembelajaran matematika, (2) siswa jarang mengerjakan PR, (3) siswa kurang memperhatikan penjelasan guru, dan (4) ada siswa yang tidak mencatat pelajaran yang sedang dibahas. Pembelajaran matematika di kelas VIIB SMP PGRI 4 Tirtoyudo masih menggunakan model pembelajaran konvensional, yakni model pembelajaran yang banyak didominasi oleh guru. Siswa pasif dalam menerima informasi pengetahuan dan kurang melakukan latihan soal secara intensif. Proses pembelajaran yang dilakukan dengan menggunakan model pembelajaran yang kurang bervariasi menyebabkan siswa merasa bosan dan tidak mampu belajar dalam durasi waktu yang lama (Lestari, Hariyani, \& Rahayu, 2018). Faktor-faktor penyebab tersebut diduga menjadi penyebab menurunnya prestasi belajar siswa.

Kondisi pembelajaran di atas perlu diperbaiki agar dapat meningkatkan prestasi belajar siswa. Salah satu solusi yang dianggap dapat mengatasi permasalahan pembelajaran matematika di SMP PGRI 4 Tirtoyudo adalah penerapan model pembelajaran jigsaw. Jigsaw adalah salah satu model pembelajaran yang bertujuan untuk mengubah perilaku siswa yang semula pasif menjadi aktif. Pebelajar aktif mengkonstruksi terus-menerus, sehingga selalu terjadi perubahan konsep menuju konsep yang lebih rinci, lengkap, serta sesuai dengan konsep ilmiah (Listiani, Kurniawati, \& Purnamasari, 2018). Pada model ini, siswa menempati posisi sangat dominan. Dalam proses pembelajaran, terjadi kerjasama dalam kelompok, semua siswa berusaha untuk memahami semua materi yang diajarkan, setiap siswa bertanggungjawab menguasai materi dan membantu memahamkan rekan siswa satu sama lain. Menurut Isjoni (2013), model pembelajaran jigsaw merupakan salah satu tipe pembelajaran kooperatif yang mendorong siswa aktif dan saling membantu dalam menguasai materi pelajaran untuk mencapai prestasi yang maksimal. Dalam penyelenggaraan model pembelajaran jigsaw, siswa dibagi menjadi beberapa kelompok belajar yang heterogen. Pembagian kelompok terbagi atas kelompok asal dan kelompok ahli. Jumlah siswa yang bekerjasama dalam masing-masing kelompok harus dibatasi, agar kegiatan belajar dapat berlangsung secara efektif.

Langkah-langkah model pembelajaran jigsaw yang dilakukan pada penelitian ini adalah sebagai berikut.

1. Menjelaskan langkah model pembelajaran jigsaw.

2. Membagi siswa menjadi beberapa kelompok. Setiap kelompok terdiri atas 4 siswa yang mempunyai kemampuan akademik heterogen.

3. Membagi lembar kerja kelompok dengan sub-materi yang berbeda kepada masing-masing anggota kelompok (kelompok asal).

4. Meminta anggota kelompok yang mempelajari materi yang sama berkumpul membentuk kelompok ahli.

5. Meminta kelompok ahli untuk mendiskusikan materi bagiannya.

6. Memantau jalannya diskusi kelompok dan memberikan bantuan jika ada siswa yang mengalami kesulitan.

7. Meminta siswa kembali ke kelompok asal dan menjelaskan materi yang dipelajari di kelompok ahli kepada rekan kelompoknya.

8. Menunjuk salah satu kelompok untuk mempresentasikan hasil diskusi kelompoknya di depan kelas. 
9. Menganalisis dan memberikan tambahan jika hasil presentasi kurang lengkap.

10. Bersama siswa membuat kesimpulan tentang materi yang telah dipelajari.

Model pembelajaran jigsaw cocok diterapkan di kelas VIIB SMP PGRI 4 Tirtoyudo karena adanya indikasi kecenderungan siswa yang mampu belajar dalam tim. Oleh karena itu, penelitian ini bertujuan untuk mendeskripsikan penerapan model pembelajaran jigsaw dalam rangka meningkatkan prestasi siswa terutama dalam materi segiempat.

\section{Metode Penelitian}

Dalam penelitian ini, peneliti menggunakan pendekatan kualitatif. Jenis penelitian yang digunakan adalah penelitian tindakan kelas (PTK), ini dikarenakan masalah muncul dari praktek pembelajaran di kelas. Selanjutnya dilakukan tindakan perbaikan untuk meningkatkan prestasi belajar siswa. Sesuai dengan pendekatan dan jenis penelitian yang telah diuraikan di atas, maka kehadiran peneliti di lapangan mutlak diperlukan. Peneliti bertindak sebagai perencana, pelaksana, pengumpul data, penganalisis data, dan pembuat laporan, sedangkan kedua peneliti anggota bertindak sebagai pengamat.

Penelitian dilaksanakan di SMP PGRI 4 Tirtoyudo kelas VIIB yang beralamatkan di Jalan Lapangan Desa Sumber Tangkil Kecamatan Tirtoyudo Kabupaten Malang. Kurikulum yang digunakan di SMP PGRI 4 Tirtoyudo adalah Kurikulum Tingkat Satuan Pendidikan (KTSP).

Subjek penelitian ini adalah siswa kelas VIIB SMP PGRI 4 Tirtoyudopada semester genap tahun pelajaran 2017/2018. Siswa kelas VIIB sebanyak 24 anak, terdiri atas 12 siswa laki-laki dan 12 siswa perempuan. Pemilihan sumber data siswa ini berdasarkan pertimbangan adanya masalah di kelas tersebut. Peneliti sebagai pengajar merupakan sumber data lain.

Prosedur yang digunakan dalam pengumpulan data meliputi observasi dan tes. Observasi dilakukan melalui kegiatan pengamatan terhadap aktivitas peneliti dan siswa selama proses pembelajaran dengan model jigsaw. Kegiatan observasi bertujuan untuk mengetahui kesesuaian antara pelaksanaan tindakan dengan perencanaan yang telah dibuat sebelumnya. Kegiatan yang diamati berupa aktivitas peneliti dan aktivitas siswa selama proses pembelajaran. Sedangkan tes bertujuan untuk mengetahui prestasi belajar siswa. Tes yang dimaksud adalah tes yang dilaksanakan setelah tindakan pembelajaran. Adapun indikator keberhasilan penelitian adalah minimal $75 \%$ siswa memenuhi keberhasilan proses dan hasil.

Analisis data pada penelitian ini dilakukan selama dan setelah pengumpulan data. Data penelitian yang terkumpul dianalisis menggunakan model alir Sugiyono (2016) dengan tahapan: (1) reduksi data, (2) penyajian data, dan (3) penarikan kesimpulan.

Pengecekan keabsahan data pada penelitian ini digunakan untuk mengecek validitas data. Cara pengecekan keabsahan data pada penelitan ini meliputi: (1) ketekunan pengamatan, (2) triangulasi, dan (3) pemeriksaan sejawat (Moleong, 2017).

\section{Hasil dan Pembahasan}

Peneliti bersama guru matematika mendapatkan kesepakatan-kesepakatan sebagai berikut:

1. Peneliti bertindak sebagai guru

2. Peneliti lain bersama guru matematika bertindak sebagai observer 
3. Siswa yang ditentukan sebagai subjek penelitian adalah siswa kelas VII-B

4. Materi yang digunakan adalah materi segiempat dengan sub bab menentukan keliling dan luas persegi, persegi panjang, belah ketupat serta jajar genjang

5. Penelitian dilaksanakan dengan menggunakan model pembelajaran jigsaw berbantuan LKK

6. Peneliti menggunakan daftar nilai ulangan tengah semester (UTS) sebagai acuan dalam pembentukan kelompok.

Pelaksanaan setiap tindakan melalui beberapa tahapan siklus yaitu perencanaan, pelaksanaan, observasi, dan refleksi. Pada perencanaan tindakan, beberapa hal yang disiapkan meliputi:

1. Membuat RPP meliputi: kompetensi inti, kompetensi dasar, indikator pembelajaran, tujuan pembelajaran, materi, dan langkah-langkah pembelajaran;

2. Menyiapkan media pembelajaran yaitu Lembar Kerja Kelompok;

3. Menyusun tes akhir;

4. Menyiapkan pedoman observasi aktivitas guru dan siswa.

Tindakan siklus 1 diawali dengan mengucapkan salam, mengecek kehadiran siswa, menanyakan kesiapan siswa mengikuti pembelajaran, kemudian peneliti menyampaikan tujuan pembelajaran yang ingin dicapai serta model pembelajaran yang akan digunakan yaitu jigsaw. Pada saat peneliti menyampaikan tujuan pembelajaran, siswa tampak lebih bersemangat mengikuti pembelajaran. Kondisi tersebut sesuai dengan pendapat Rusman (2017) yang menyatakan bahwa bila siswa sudah mengetahui tujuan pembelajaran yang sedang mereka ikuti, maka mereka akan terdorong untuk melaksanakan kegiatan tersebut secara aktif.

Selanjutnya, siswa dibagi menjadi 6 kelompok. Setiap kelompok terdiri atas 4 siswa yang berkemampuan heterogen, yaitu siswa yang berkemampuan akademik tinggi, sedang, dan rendah. Tujuan pembentukan kelompok dengan anggota heterogen adalah agar siswa dapat berdiskusi dan bekerjasama dengan baik demi keberhasilan kelompok.

Setelah membentuk kelompok, peneliti meminta siswa berkumpul sesuai dengan anggota kelompoknya. Siswa dengan tenang memperhatikan arahan guru dan menempati meja yang ditentukan, tetapi beberapa saat kemudian suasana kelas menjadi ramai. Kondisi tersebut disebabkan karena ada siswa tidak setuju dengan anggota kelompoknya. Untuk meredam kegaduhan tersebut, peneliti meminta siswa tenang dan meminta nama-nama siswa yang dipanggil segera bergabung dengan kelompoknya.

Selanjutnya peneliti membagikan LKK yang terdiri atas 4 sub bab materi kepada setiap kelompok asal. Tiap siswa memilih dan membaca satu lembar kerja yang akan menjadi tanggung jawabnya, kemudian setiap anggota kelompok yang bertugas mempelajari materi yang sama berkumpul membentuk kelompok baru yaitu kelompok ahli. Kelompok ahli mendiskusikan masalah pada LKK. Pada saat diskusi, peneliti bertindak sebagai fasilitator dan mengamati jalannya diskusi. Selain itu, peneliti juga menyampaikan arahan agar siswa tidak bingung. Hal ini sesuai dengan pendapat Djamarah \& Zain (2010) yang menyatakan bahwa guru harus memberikan arahan serta petunjuk yang jelas dan singkat dalam menyampaikan pelajaran kepada siswa, sehingga tidak terjadi kebingungan pada diri siswa.

Kemudian peneliti meminta kelompok ahli kembali ke kelompok asal. 
Masing-masing anggota kelompok menjelaskan materi yang menjadi keahliannya kepada rekan kelompok asal. Kegiatan selanjutnya adalah mempresentasikan hasil diskusi kelompok, peneliti meminta perwakilan kelompok asal untuk menyampaikan hasil diskusinya. Akan tetapi, siswa tidak berani mempresentasikan hasil diskusinya. Peneliti memberikan motivasi agar siswa berani menyampaikan pendapat di hadapan siswa lain. Hal ini sesuai dengan pendapat Dimyati \& Mudjiono (2009) yang menyatakan bahwa guru perlu memotivasi siswa dengan memberikan rasa percaya diri bahwa ia dapat mengatasi segala hambatan dan berhasil.

Setelah presentasi selesai, peneliti mengajak siswa menyimpulkan materi yang telah dipelajari yaitu luas dan keliling persegi dan persegi panjang. Kegiatan ini dilakukan dengan tujuan untuk mempertahankan daya ingat siswa terhadap materi yang telah dipelajari. Hal ini sesuai dengan pendapat Sanjaya (2015) yang mengemukakan bahwa rangkuman atau kesimpulan perlu dilakukan dengan maksud meninjau kembali (review) terhadap materi yang telah dipelajari.

Kegiatan pembelajaran diakhiri dengan pelaksanaan tes uji pemahaman (tes akhir siklus 1). Tes ini dilakukan untuk mengetahui pemahaman siswa terhadap materi yang telah dipelajari. Selama tes, tampak beberapa siswa berusaha menyontek jawaban siswa lainnya. Keadaan ini menunjukkan bahwa masih ada siswa yang tidak percaya diri dalam menjawab soal dengan kemampuannya sendiri, selain itu, siswa takut gagal dan mendapatkan nilai yang tidak memuaskan. Hal ini sesuai dengan pendapat Dimyati \& Mudjiono (2009) yang menyatakan bahwa bila rasa tidak percaya diri sangat kuat, maka diduga siswa akan menjadi takut belajar. Rasa takut belajar tersebut terjalin secara komplementer dengan rasa takut gagal lagi.

Adapun aktivitas peneliti pada kegiatan siklus 1 berjalan dengan baik sesuai dengan rencana yang telah disusun. Hal tersebut dapat dilihat pada hasil analisis lembar observasi guru yang menunjukkan bahwa persentase keberhasilan aktivitas peneliti sebesar $87,5 \%$. Namun demikian, peneliti masih kurang bisa mengalokasikan waktu.

Aktivitas siswa pada kegiatan siklus 1 pada hasil analisis lembar observasi siswa menunjukkan persentase keberhasilan sebesar $85 \%$, akan tetapi siswa gaduh pada saat pembagian kelompok. Ada siswa yang mendominasi kegiatan mengerjakan tugas dalam kelompok. Pada saat persentasi kelompok, beberapa siswa yang tidak persentasi kurang memperhatikan dan berbicara dengan temannya. Beberapa siswa kurang percaya diri ketika mengikuti tes.

Hasil analisis tes siklus 1 menunjukkan bahwa siswa yang tuntas belajar sebanyak 19 siswa dari 24 siswa, sehingga persentase siswa yang tuntas belajar sebesar $79,10 \%$ dan persentase siswa yang tidak tuntas belajar sebesar 20,90\% dengan nilai rata-rata kelas 73,5. Ketuntasan prestasi belajar siswa sebelum siklus 1 dilaksanakan sebesar $70,8 \%$. Dengan demikian peningkatan prestasi belajar siswa mencapai 8,3\%.

Berdasarkan hasil refleksi dan diskusi dengan observer, peneliti melaksanakan siklus 2 dengan melakukan perbaikan terhadap beberapa kekurangan pada pembelajaran siklus 1 . Selain itu, pembelajaran siklus 2 dilaksanakan karena peneliti yakin ada beberapa siswa yang belum tuntas masih bisa mencapai nilai KKM (tuntas belajar).

Pada siklus 2, peneliti memperbaiki kekurangan-kekurangan yang terjadi pada siklus 1. Beberapa 
kekurangan pada pembelajaran siklus 1 antara lain:

1. Siswa gaduh pada saat pembagian kelompok karena tidak satu kelompok dengan teman yang diharapkan

2. Ada siswa yang mendominasi kegiatan mengerjakan LKK

3. Saat presentasi berlangsung beberapa siswa berbicara dengan temannya dan tidak memperhatikan presentasi kelompok

4. Beberapa siswa kurang percaya diri saat mengikuti tes.

Agar semua anggota kelompok dapat aktif dalam berdiskusi dan tidak ada siswa yang mendominasi mengerjakan LKK, peneliti menginstruksikan setiap kelompok memilih satu siswa untuk menjadi ketua kelompok. Ketua kelompok bertugas mengatur jalannya diskusi kelompok, sehingga semua anggota aktif dalam berdiskusi. Hal ini sesuai dengan pendapat Anam (2016) bahwa ketua kelompok merupakan seseorang yang bertugas memberikan pengarahan kepada anggota tentang masalah yang akan didiskusikan (ruang lingkup diskusi), membuka kesempatan kepada semua anggota untuk mengungkapkan pendapatnya, sehingga semua anggota diskusi dapat aktif berdiskusi.

Pada saat presentasi, peneliti memberikan hukuman kepada siswa yang tidak memperhatikan atau berbicara dengan teman lain, dengan cara ikut berdiri di depan kelas bersama kelompok yang sedang presentasi. Pemberian hukuman (sanksi) dimaksudkan agar siswa memperhatikan teman yang sedang presentasi dan tidak berbicara dengan teman lain, sehingga presentasi berjalan dengan tertib. Hal ini sejalan dengan pendapat Djamarah \& Zain (2010) bahwa hukuman (punishment) akan membuat siswa merasa jera dan membuat siswa memperhatikan pelajaran.
Kegiatan pembelajaran diakhiri dengan tes. Pada saat tes, peneliti berkeliling memastikan tidak ada siswa yang menyontek. Siswa tampak mengerjakan soal tes dengan tenang, serius, dan percaya diri dengan kemampuan sendiri. Hal ini sesuai dengan pendapat Kushartanti (2009) yang menyatakan bahwa kepercayaan diri yang tinggi akan membiasakan siswa untuk bersikap positif terhadap kemampuannya dan tidak terpengaruh oleh orang lain. Rasa percaya diri siswa untuk tidak menyontek pekerjaan siswa lain menunjukkan bahwa siswa memahami materi yang telah dipelajari. Dengan demikian, dapat diketahui seberapa jauh keberhasilan program pembelajaran yang telah dilakukan dalam rangka mencapai tujuan atau kompetensi yang telah ditetapkan.

Aktivitas guru pada kegiatan siklus 2 berlangsung sesuai dengan rancangan persiapan. Hal tersebut dapat dilihat pada hasil analisis lembar observasi guru yang menunjukkan bahwa prosentase keberhasilan aktivitas guru sebesar 93,75\%. Dengan demikian peningkatan prosentase aktivitas guru sebesar 6,25\%.

Aktivitas siswa pada kegiatan siklus 2 menunjukkan prosentase keberhasilan sebesar 90\%. Oleh karena itu, peningkatan prosentase aktivitas siswa mencapai 5\%. Pada siklus 2, siswa tidak gaduh saat pembagian kelompok dan kembali ke bangku masing-masing pada akhir pembelajaran. Peneliti menerapkan aturan yang jelas, sehingga siswa dapat dikendalikan dengan baik. Siswa sudah mulai aktif dalam mengikuti diskusi kelompok untuk menyelesaikan lembar kerja kelompok. Siswa lebih percaya diri ketika mengikuti tes. Selain itu, peneliti sudah bisa mengkontrol waktu sehingga pembelajaran selesai tepat waktu. 
Hasil tes analisis siklus 2 menunjukkan bahwa siswa yang tuntas belajar sebanyak 22 siswa dari 24 siswa, sehingga prosentase siswa yang tuntas belajar sebesar $91,67 \%$ dan prosentase siswa yang tidak tuntas belajar sebesar $8,33 \%$ dengan nilai rata-rata kelas 80,2. Dengan demikian peningkatan prosentase ketuntasan klasikal sebesar 12,57\%.

Hal tersebut menunjukkan bahwa pembelajaran dengan menggunakan model pembelajaran jigsaw dapat meningkatkan prestasi belajar siswa SMP PGRI 4 Tirtoyudo.

Peneliti melakukan diskusi dengan guru matematika dan teman sejawat dalam melakukan refleksi tentang berbagai kendala yang terjadi pada saat pembelajaran. Pada saat proses pembelajaran berlangsung, peneliti sudah berusaha memperbaiki kekurangan yang terjadi pada siklus 1. Dengan adanya perbaikan tersebut, interaksi peneliti dan siswa pada siklus 2 menjadi lebih aktif dan efektif. Suasana pembelajaran menjadi lebih menarik dan menyenangkan. Siswa bertanggung jawab dengan tugas masing-masing, sehingga diskusi yang dilakukan berjalan dengan lancar.

Berdasarkan hasil refleksi di atas, peneliti tidak perlu melaksanakan siklus selanjutnya. Hal ini menunjukkan bahwa penelitian yang dilakukan dapat meningkatkan prestasi belajar siswa SMP PGRI 4 Tirtoyudo.

\section{Kesimpulan}

Berdasarkan hasil penelitian, maka kesimpulan yang dapat diambil adalah sebagai berikut.

1. Pembelajaran model jigsaw dapat meningkatkan prestasi belajar materi segiempat dapat dilakukan dengan langkah-langkah sebagai berikut:

a. Guru menjelaskan langkah model pembelajaran jigsaw. b. Guru membagi siswa di kelas menjadi beberapa kelompok. Setiap kelompok terdiri atas 4 siswa yang mempunyai kemampuan akademik heterogen.

c. Guru membagi Lembar Kerja Kelompok dengan sub-materi yang berbeda kepada masingmasing anggota kelompok (kelompok asal).

d. Guru meminta anggota kelompok yang mempelajari materi yang sama berkumpul membentuk kelompok ahli.

e. Guru meminta kelompok ahli untuk mendiskusikan materi bagiannya.

f. Guru memantau jalannya diskusi kelompok dan memberikan bantuan jika ada siswa yang mengalami kesulitan

g. Guru meminta siswa kembali ke kelompok asal dan menjelaskan materi yang dipelajari di kelompok ahli kepada rekan kelompoknya.

h. Guru menunjuk salah satu kelompok untuk mempresentasikan hasil diskusi kelompoknya di depan kelas.

i. Guru menganalisis dan memberikan tambahan jika hasil presentasi kurang lengkap.

j. Guru bersama siswa membuat kesimpulan tentang materi yang telah dipelajari.

2. Prosentase aktivitas guru pada kegiatan siklus 1 sebesar $87,5 \%$ dan siklus 2 sebesar $93,75 \%$, sedangkan prosentase aktivitas siswa pada siklus 1 sebesar $85 \%$ dan siklus 2 sebesar $90 \%$.

3. Prosentase ketuntasan siswa pada tahap pra tindakan sebesar $70,8 \%$ menjadi $79,10 \%$ pada tes akhir siklus 1, dan $91,67 \%$ pada tes akhir siklus 2. Dengan demikian, prestasi siswa mengalami peningkatan dari setiap 
siklus. Peningkatan dari tahap pra tindakan ke siklus 1 sebesar 8,3\%, sedangkan peningkatan dari siklus 1 ke siklus 2 sebesar 12,57\%. Berdasarkan hasil tersebut, dapat disimpulkan bahwa model pembelajaran jigsaw dapat meningkatkan prestasi belajar siswa.

Berdasarkan kesimpulan penelitian tindakan di kelas VIIB SMP PGRI 4 Tirtoyudo, beberapa saran yang perlu disampaikan.

1. Guru lebih mengalokasikan waktu dengan baik agar tujuan pembelajaran materi segiempat yang direncanakan dapat tercapai.

2. Pada saat diskusi, sebaiknya guru aktif memantau, membimbing, dan memotivasi agar aktivitas siswa berjalan sesuai dengan tujuan yang direncanakan.

\section{Daftar Rujukan}

Anam, R. S. (2016). Efektivitas Dan Pengaruh Model Pembelajaran Inkuiri Pada Pembelajaran Ipa Di Sekolah Dasar. Mimbar Sekolah Dasar.

https://doi.org/10.17509/mimbarsd.v2i1.1334

Dimyati, \& Mudjiono. (2009). Konsentrasi Belajar. Kesehatan Mental.

Djamarah, S. B., \& Zain, A. (2010). Guru dan Anak Didik dalam Interaksi Edukatif Suatu Pendekatan Teoritis Psikologis. Jakarta:Rineka Cipta.

Rusman. (2017). Belajar \&

Pembelajaran: Berorientasi Standar Proses Pendidikan. PT Kharisma Putra Utama.

https://doi.org/JFDS354

[pii] \r10.1111/j.1750-

3841.2007.00354.x
Isjoni, H. (2013). Cooperative Learning efektifitas pembelajaran kelompok. Bandung:

Alfabeta. https://doi.org/10.1038/nmeth.2839.

A

Kushartanti, A. (2009). Perilaku Menyontek Ditinjau dari Kepercayaan Diri. Indigenous: Jurnal Ilmiah Psikologi.

Lestari, S. E. C. A., Hariyani, S., \& Rahayu, N. (2018). Pembelajaran Kooperatif Tipe Tgt (Teams Games Tournament) Untuk Meningkatkan Hasil Belajar Matematika. Pi: Mathematics Education Journal, 1(3), 116-126. https://doi.org/10.21067/pmej.v1i3.2 785

Listiani, W., Kurniawati, A., \& Purnamasari, I. O. (2018). Efektifitas Tutor Sebaya Dalam Pembelajaran Trigonometri Di Ikip Budi Utomo Malang. Pi: Mathematics Education Journal, 1(2), 70-74. https://doi.org/10.21067/pmej.v1i2.2 328

Moleong, L. J. (2017). Metodologi Penelitian Kualitatif (Edisi Revisi). In PT. Remaja Rosda Karya.

Mulyasa, E. (2013). Menjadi Guru Profesional Menciptakan Pembelajaran Kreatif dan Menyenangkan. Remaja Rosdakarya. https://doi.org/10.1063/1.3677665

Sanjaya, W. (2015). Perencanaan dan Desain Sistem Pembelajaran.

Silberman, M. L. (2005). 101 ways to make training active / $\mathrm{Mel}$ Silberman. One hundred one ways to make training active.

Sugiyono. (2016). Memahami Penelitian Kualitatif. Bandung: Alfabeta. 